\title{
Beneficial Effect of Combined Administration of Vitamin C and Vitamin E in Amelioration of Chronic Lead Hepatotoxicity
}

\author{
Samir A.E. Bashandy \\ Zoology Department, College of Science, King Saud univrsity Saudi Arabia
}

\begin{abstract}
Introduction: Oxidative stress with subsequent lipid peroxidation has been postulated as one mechanism for lead toxicity. The protective action of vitamins $\mathrm{C}$ and $\mathrm{E}$ against lead affects lipid hydroperoxide level and liver functions in male rats has been studied.

Results: Administration of lead acetate (2\%) in dirinking water for 3 months elevates plasma lipid hydroperoxide level, activities of aspartate aminotronsferase (AST), alanine aminotransferase (ALT) and alkaline phosphatase (ALP), cholesterol, triglycerides and low density lipoprotein (LDL) levels. On the other hand, reduced plasma glutathione (GSH), protein and high density lipoprotein (HDL) concentrations lowered significantly in lead $(\mathrm{Pb})$ treated group. However, oral administration of vitamin $\mathrm{C}$ (Vit C) or vitamin $\mathrm{E}$ (Vit $\mathrm{E}$ ) at dose level of $100 \mathrm{mg} / \mathrm{kg}$ body weight reduced the alterations in the previous parameters. On the other hand, co-administration of both vitamins (Vit $\mathrm{C}+\mathrm{Vit} \mathrm{E}$ ) to lead-treated rats led to the most significant decline in lipid hydroperoxide level, restoration of GSH level and exhibited more protection as compared with Vit C or Vit E separately.

Conclusion: There is synergistic antioxidative effect between Vit $\mathrm{C}$ and Vit $\mathrm{E}$ that protects the liver from lead induced lipid peroxidation, suggesting that the antioxidant treatment may best be done using a balanced cocktail. .
\end{abstract}

\section{Introduction}

Lead $(\mathrm{Pb})$ is environmental and indiustrial pollutant that has undesired effects, including growth retardation (Shukla et al., 1991) immunological (Ercal et al., 2000), hepatic (Sivaprasad et al., 2004) and reproductive disfunctions (Winder, 1993). $\mathrm{Pb}$ caused lymphocyte infiltration and cirrhosis of liver cells (Sipos et al., 2003). Hepatic disorders were noticed in rats as manifested by increase of liver enzymes (Jevtovic-Stonimenov et al., 2003). Activation of free radical processes and impairment of the antioxidant defense system are likely to be one of the basic mechanisms responsible for hepatic damage during prolonged lead intoxication (ElSokkary et al., 2005). Treatment of rats with $\mathrm{Pb}$ increased reactive oxygen species (ROS) that may contribute to hypertension and tissue damage (Vaziri et al., 1999).

Vitamins are essential to maintain normal metabolic processes and homeostasis within the body. Vitamin $\mathrm{C}$ (Vit C) and vitamin E (Vit E) are low molecular mass antioxidants that scavenge or quench free radicals (Janisch et al., 2005). Reactive oxygen species (ROS) related lead toxicity in the rat sperm was prevented by Vit C or Vit E (Hsu et al., 1998). These findings suggest potential role of antioxidants to ameliorate lead toxicity. Moreover, the Co-treatment of $\mathrm{Pb}$-injected mice with both vitamin $\mathrm{C}$ and $\mathrm{E}$ inhibited cytotoxic effects of lead on the testes (Mishra and Acharya, 2004). Both Vit C and Vit $\mathrm{E}$ alleviate oxidative stress associated with a variety of pollutants. Vit $\mathrm{C}$ and Vit $\mathrm{E}$ reduced lipid peroxidation and oxidative stress result from arsenic (Kannan and Flora, 2004), Ozone (SienraMonge, 2004) and cadmium (Grosicki, 2004) toxicities. Combined treatment with vitamin $\mathrm{C}$ and vitamin $\mathrm{E}$ exhibited a good protection against thioacetamide (Ming et 
al., 2006) and radiation (Wan et al., 2006) induced oxidative stress. Hence, the current study was designed to investigate the combined effects of vitamin $\mathrm{C}$ and vitamin $\mathrm{E}$ on alleviation the hepatotoxicity during lead exposure.

\section{Material And Methods}

\section{Animals and experimental design}

Forty male Sprague Dawley rats weighting 160-200 g, from the college of pharmacy, king Saud university were maintained in the animal house under controlled conditions $(12 \mathrm{~h}$ light, temperature $22 \pm 1^{\circ} \mathrm{C}$ ) and were given dry ration and water ad lib. The animals were assigned to five groups, each of which contained 8 rats. The rats were treated daily for 3 months as follows: group (1) not treated and kept as control, group (2) treated with $2 \%$ lead acetate in drinking water, group (3) administered vitamin C $(100 \mathrm{mg} / \mathrm{kg})$ beside lead $(2 \%)$ in drinking water, group (4) given vitamin E $(100 \mathrm{mg} / \mathrm{kg})$ orally and $\mathrm{Pb}$ in drinking water and group (5) given the two vitamins in combination + lead acetate. Vit C, Vit E and $\mathrm{Pb}$ were procured from Sigma chemicals, USA. Blood was collected from eyes of the animals monthly for 3 months and plasma was separated and kept in deep freezer $\left(-20^{\circ} \mathrm{C}\right)$ until analysis.

\section{Measurements}

Blood levels of hydroperoxide were evaluated using free radical analytical system (IRAM, PARMA, Italy). The test is a colorimetric test that takes advantage of the ability of hydroperoxides to generate free radicals after reacting with some transitional metals. (Wolff, 1994).

Reduced glutathione was measured using the method of Beutler et al. (1963).

Plasma total protein (Gornall et al., 1949), AST, ALT (Reitman and Frankel, 1957), alkaline phosphatase (Kind and King, 1954), cholesterol (Allain et al., 1974), triglycerides (Fossati and Prencipe, 1982), HDL and LDL-cholesterol (Lopez-
Virella, 1977) were determined using biomerieux kits.

\section{Statistical analysis:}

The values are expressed as mean \pm S.E. the results were computed statistically (SPSS program) using one way analysis of variance.

\section{Results}

\section{Lipid hydroperoxide}

A distinct and significant elevation in the hydroperoxide level $(\mathrm{P}<0.01)$ was found in Pb-treated rats (Fig. 1A) as compared to control group at all time intervals. Moreover, the hydroperoxide level of rats treated with $\mathrm{Vit} \mathrm{C}+\mathrm{Pb}$, Vit $\mathrm{E}+\mathrm{Pb}$ and Vit $\mathrm{C}+\mathrm{Vit} \mathrm{E}+\mathrm{Pb}$ increased significantly $(\mathrm{P}<0.01)$ after 3 months as compared to control. The Vit $\mathrm{C}$ supplemented group showed a significantly $(\mathrm{P}<0.01)$ lower hydroperoxide level as compared to $\mathrm{Pb}$-treated group at the three time intervals, while similar result was recorded in Vit E-treated group at third month only. Furthermore, coadministration of both vitamins to $\mathrm{Pb}$ treated rats markedly reduced hydroperoxide level $(\mathrm{P}<0.01)$ as compared to $\mathrm{pb}$ treated groups supplemented with either of the vitamins alone.

\section{Reduced glutathione in blood:}

GSH concentration in RBCs was decreased significantly $(\mathrm{P}<0.01)$ in samples of rats treated with $\mathrm{Pb}$ only at the second and third week compared to control animals (Fig. 1B ). On the other hand, GSH level did not change significantly in rats given Vit $\mathrm{C}+\mathrm{pb}$ at any time interval as compared to control. GSH level showed a significant decrease $(\mathrm{P}<0.01)$ in the rats subjected to Vit $\mathrm{E}+\mathrm{Pb}$ as compared to control at third month. The rats treated with $\mathrm{Vit} \mathrm{C}+\mathrm{Pb}$, Vit $\mathrm{E}+\mathrm{Pb}$ and $\mathrm{Vit} \mathrm{C}+\mathrm{Vit} \mathrm{E}+\mathrm{Pb}$ have higher GSH level as compared to $\mathrm{Pb}$ group. The GSH level of rats given Vit $\mathrm{C}+\mathrm{Vit} \mathrm{E}+\mathrm{Pb}$ is significantly higher $(\mathrm{P}<0.01)$ than that of Vit $\mathrm{C}+\mathrm{Pb}$ or Vit $\mathrm{E}+\mathrm{Pb}$. 


\section{Plasma protein}

The protein concentration (Fig. 2 A) showed a significant decrease $(\mathrm{P}<0.01)$ in all treatment groups except in the group treated with Vit $\mathrm{C}+\mathrm{Vit} \mathrm{E}+\mathrm{Pb}$ throughout all the experimental periods. The protein concentration of rats treated with Vit $\mathrm{C}+$ $\mathrm{Pb}$ or $\mathrm{Vit} \mathrm{E}+\mathrm{Pb}$ is significantly $(\mathrm{P}<0.01)$ higher than that of $\mathrm{Pb}$ group at the end of third month only. Moreover, the protein level of rats given Vit $\mathrm{C}+\mathrm{Vit} \mathrm{E}+\mathrm{Pb}$ is significantly higher than those of $\mathrm{Pb}$ group, Vit $\mathrm{C}+\mathrm{Pb}$ group and $\mathrm{Vit} \mathrm{E}+\mathrm{Pb}$ group at all time intervals.

\section{Plasma liver enzymes:}

\subsection{AST}

A significant increase $(\mathrm{P}<0.01)$ in AST activity was recorded (Fig. 2 B ) in all treatment groups. On the other hand, AST activities in rats exposed to $\mathrm{Pb}$ and treated with Vit C or Vit E separately or in combination were significantly $(\mathrm{P}<0.01)$ less than in $\mathrm{Pb}$ group. AST activity in group given Vit $\mathrm{C}+\mathrm{Vit} \mathrm{E}+\mathrm{Pb}$ remained significantly less than any other treatment groups.

\subsection{ALT}

ALT activities increased significantly $(\mathrm{P}<0.01)$ in rats given $\mathrm{Pb}$ versus those of control animals at all time intervals (Fig. 3A) ALT level of rats treated with Vit E + $\mathrm{Pb}$ is significantly higher than that of control at the third month only. Nosignificant difference was noticed between control and Vit $\mathrm{C}+\mathrm{Pb}$ or Vit $\mathrm{C}+\mathrm{Vit} \mathrm{E}+$ $\mathrm{Pb}$. ALT activities of rats treated with $\mathrm{Pb}$ and supplemented with Vit C or Vit E separately or in combination are significantly less than those of $\mathrm{Pb}$ at the three time intervals. Combination of Vit $\mathrm{C}$ and Vit $\mathrm{E}$ has a pronounced protection against ALT elevation due to $\mathrm{Pb}$ treatment.

\subsection{Alkaline phosphatase}

It is observed that the alkaline phosphatase activity (Fig. $3 \mathrm{~B}$ ) of $\mathrm{Pb}$ treated rats elevated significantly $(\mathrm{P}<0.01)$ as compared to control at $2^{\text {nd }}$ and $3^{\text {rd }}$ months, while it did not change significantly in other treatment groups.

\section{Plasma lipid profile}

\subsection{Cholesterol and Triglycerides}

Lead administration alone caused a time dependent increase $(\mathrm{P}<0.01)$ in cholesterol and triglycerides levels (Fig. 4 A,B). The two parameters were increased significantly $(\mathrm{P}<0.01)$ in other treatment groups at the third month as compared to control. On the other hand, the values of both cholesterol and triglycerides of rats treated with Vit $\mathrm{C}+\mathrm{Pb}$, Vit $\mathrm{E}+\mathrm{Pb}$ and Vit $\mathrm{C}+\mathrm{Vit} \mathrm{E}+\mathrm{Pb}$ are significantly $(\mathrm{P}<0.01)$ less than those of $\mathrm{Pb}$ group. However, a more pronounced recovery in the above mentioned variables was observed after combination treatment with the two antioxidants against lead.

\subsection{HDL}

A significant decrease in HDL levels $(\mathrm{P}<0.01)$ were recorded in all treatment groups (Fig. 5A) as compared with the control. Moreover, HDL concentrations in rats exposed to lead and treated with Vit $\mathrm{C}$ or Vit E separately or in combination were significantly $(\mathrm{P}<0.01)$ higher than those of $\mathrm{Pb}$ group. The simultaneous supplementation with Vit $\mathrm{C}+\mathrm{Vit} \mathrm{E}$ to $\mathrm{Pb}$ treated rats led to an even higher $(\mathrm{P}<0.01) \mathrm{HDL}$ level compared to the administration of either of the vitamins alone.

\subsection{LDL}

Fig. (5 B) demonstrated a significant increase $(\mathrm{P}<0.01)$ in LDL concentrations of all treatment groups except in rats treated with Vit $\mathrm{C}+\mathrm{Vit} \mathrm{E}+\mathrm{Pb}$ as compared to the control. Furthermore, LDL levels of Vit $\mathrm{C}+\mathrm{Pb}$, Vit $\mathrm{E}+\mathrm{Pb}$ and Vit $\mathrm{C}+\mathrm{Vit} \mathrm{E}$ $+\mathrm{Pb}$ treated rats were significantly $(\mathrm{P}<$ 0.01) lower than in $\mathrm{Pb}$ group. Moreover, co-administration of both vitamins to $\mathrm{Pb}$ treated rats markedly reduced the elevation of LDL levels due to treatment of animals with lead. 
Fig. (1): Effect of Vitamin C / Vitamin $E$ either alone or in combination on blood hydroperoxide and GSH levels of lead exposed rats
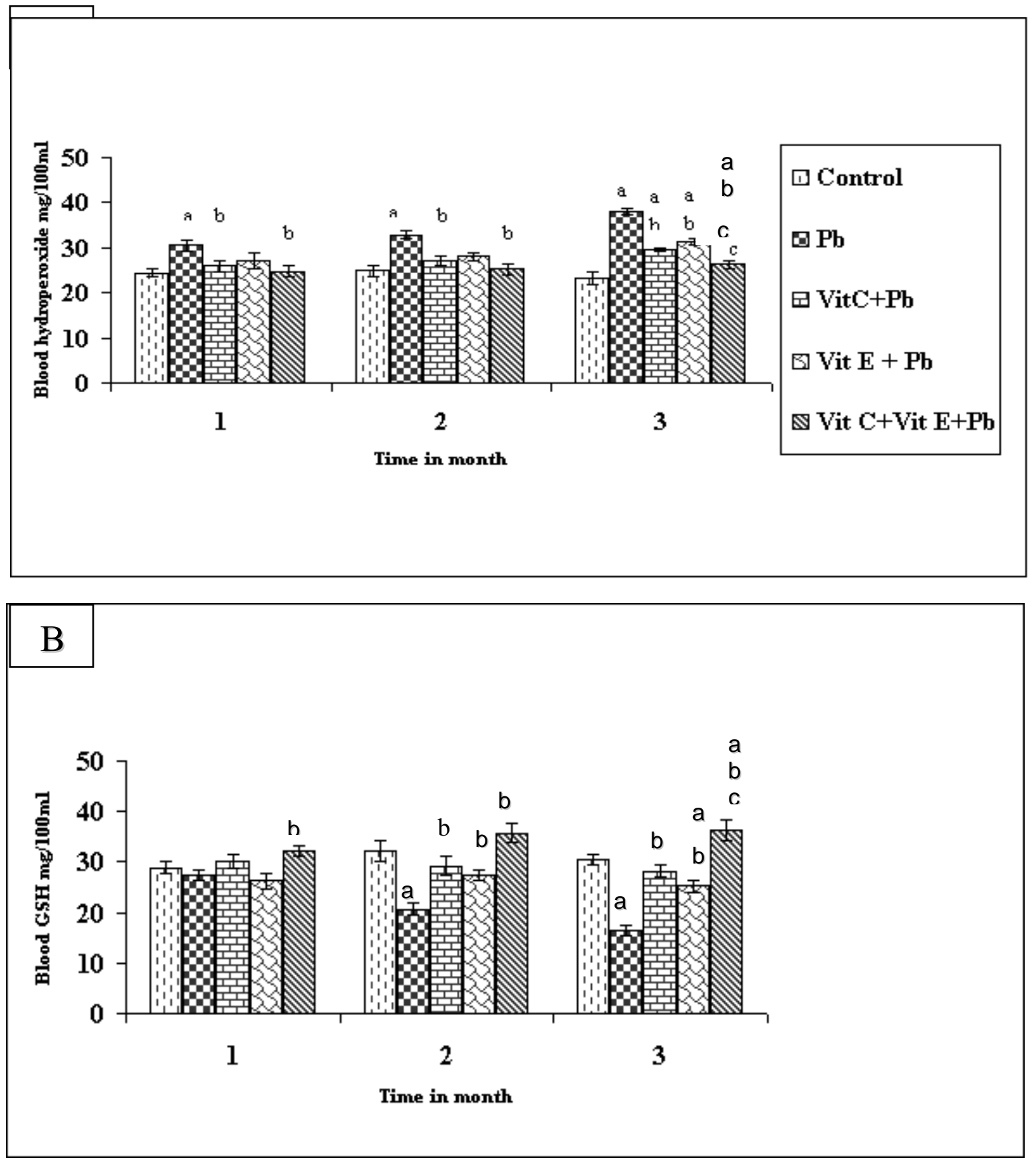

values are mean \pm S.E., $n=8$

a: Differ significantly compare to control, $\mathrm{P}<0.01$.

b: Differ significantly compare to $\mathrm{pb}, \mathrm{p}<0.01$.

C; Differe significantly compare to Vit C + pb or Vit $\mathrm{E}+\mathrm{pb}$ 
Fig. (2): Effect of Vitamin C / Vitamin E either alone or in combination on plasma levels of total protein and AST of lead treated rats
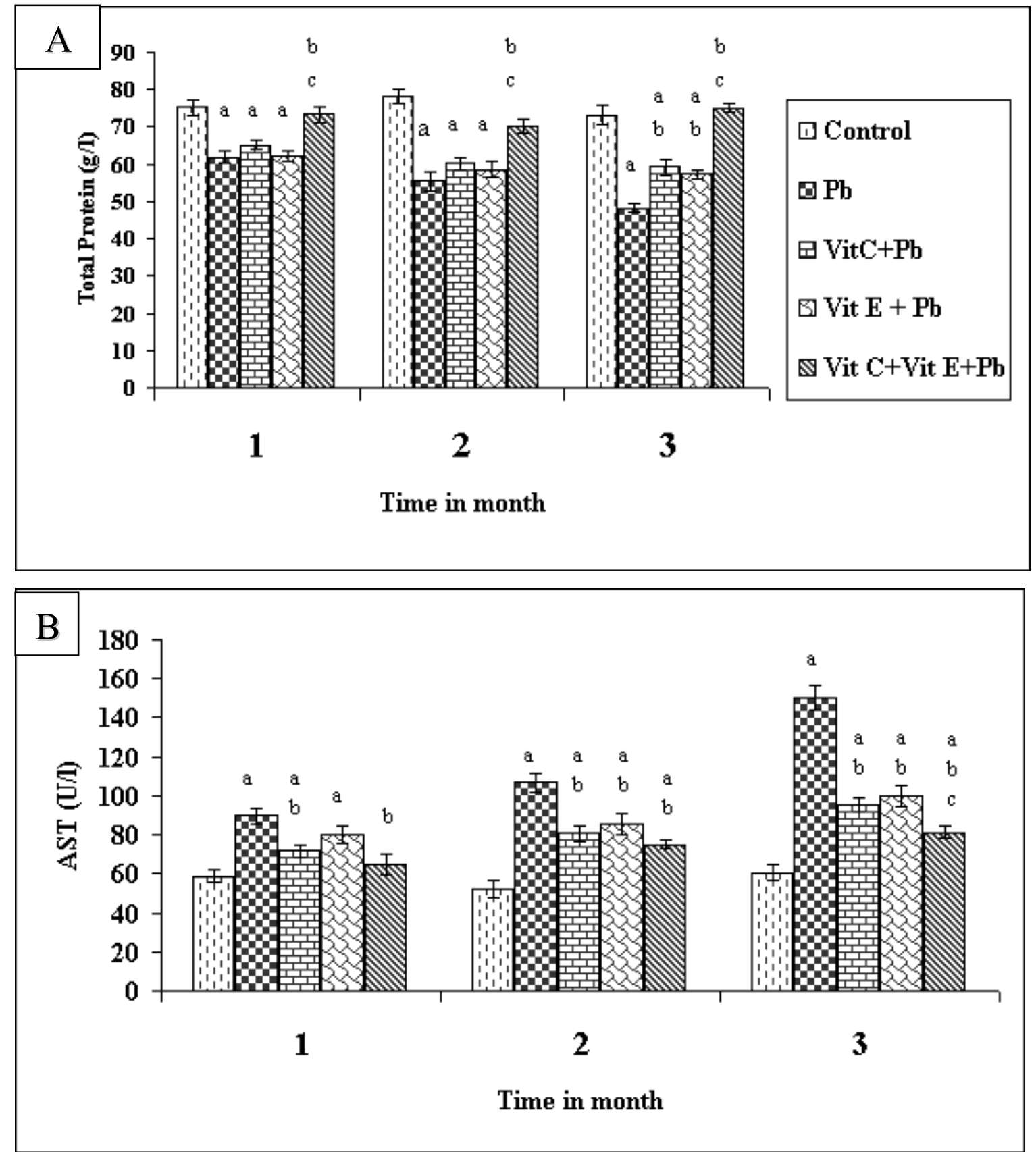

values are mean \pm S.E., $n=8$

a: Differ significantly compare to control, $\mathrm{P}<0.01$.

b: Differ significantly compare to $\mathrm{pb}, \mathrm{p}<0.01$.

C; Differe significantly compare to Vit C + pb or Vit E + pb 
Fig. (3): Effect of Vitamin C / Vitamin E either alone or in combination on plasma ALT and Alkaline phosphatase (ALP) levels of lead treated rats
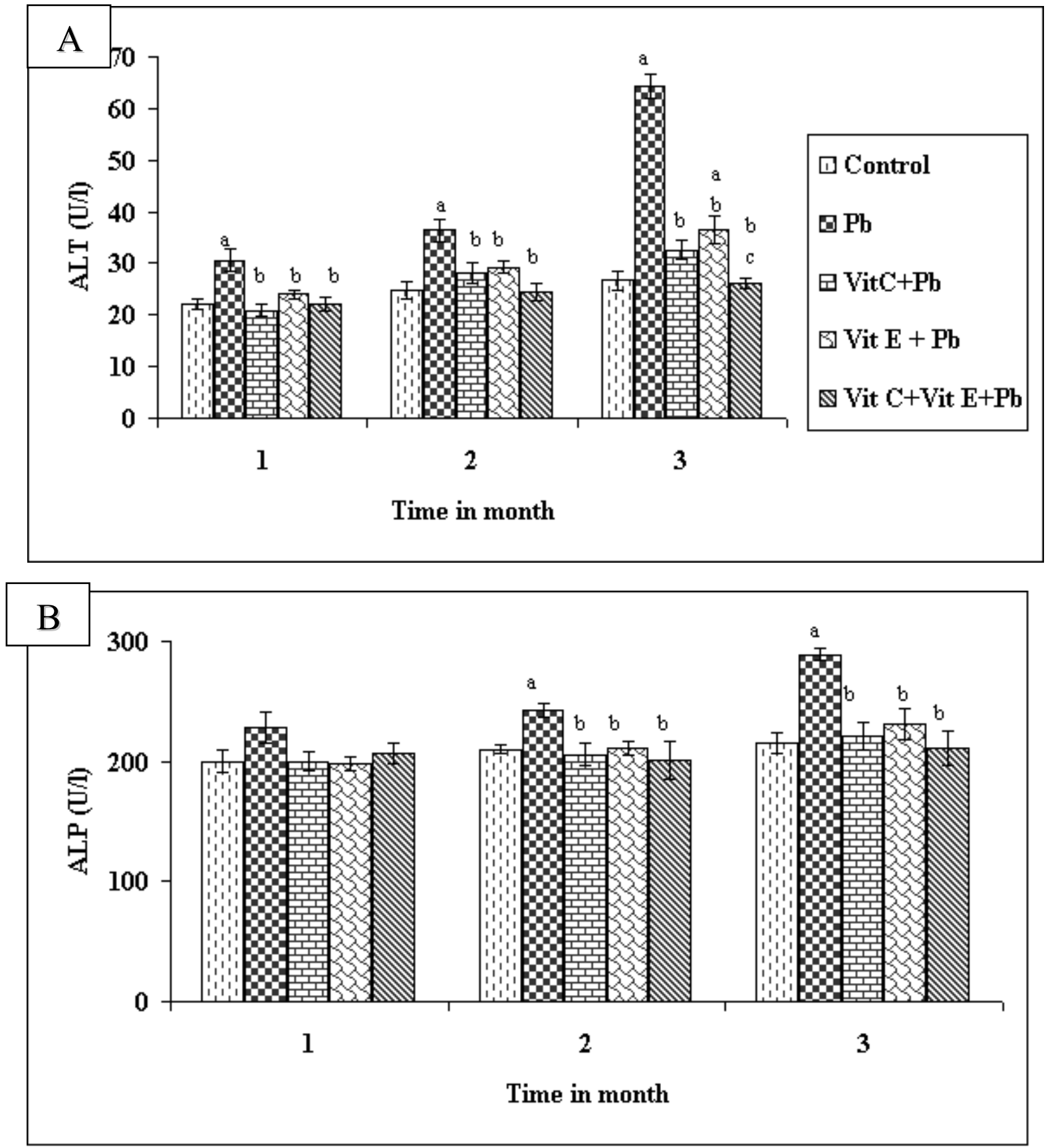

values are mean \pm S.E., $n=8$

a: Differ significantly compare to control, $\mathrm{P}<0.01$.

b: Differ significantly compare to $\mathrm{pb}, \mathrm{p}<0.01$.

C; Differe significantly compare to Vit C + pb or Vit E + pb 
Fig. (4): Effect of Vitamin C / Vitamin E either alone or in combination on plasma cholesterol and Triglycerides levels of lead treated rats
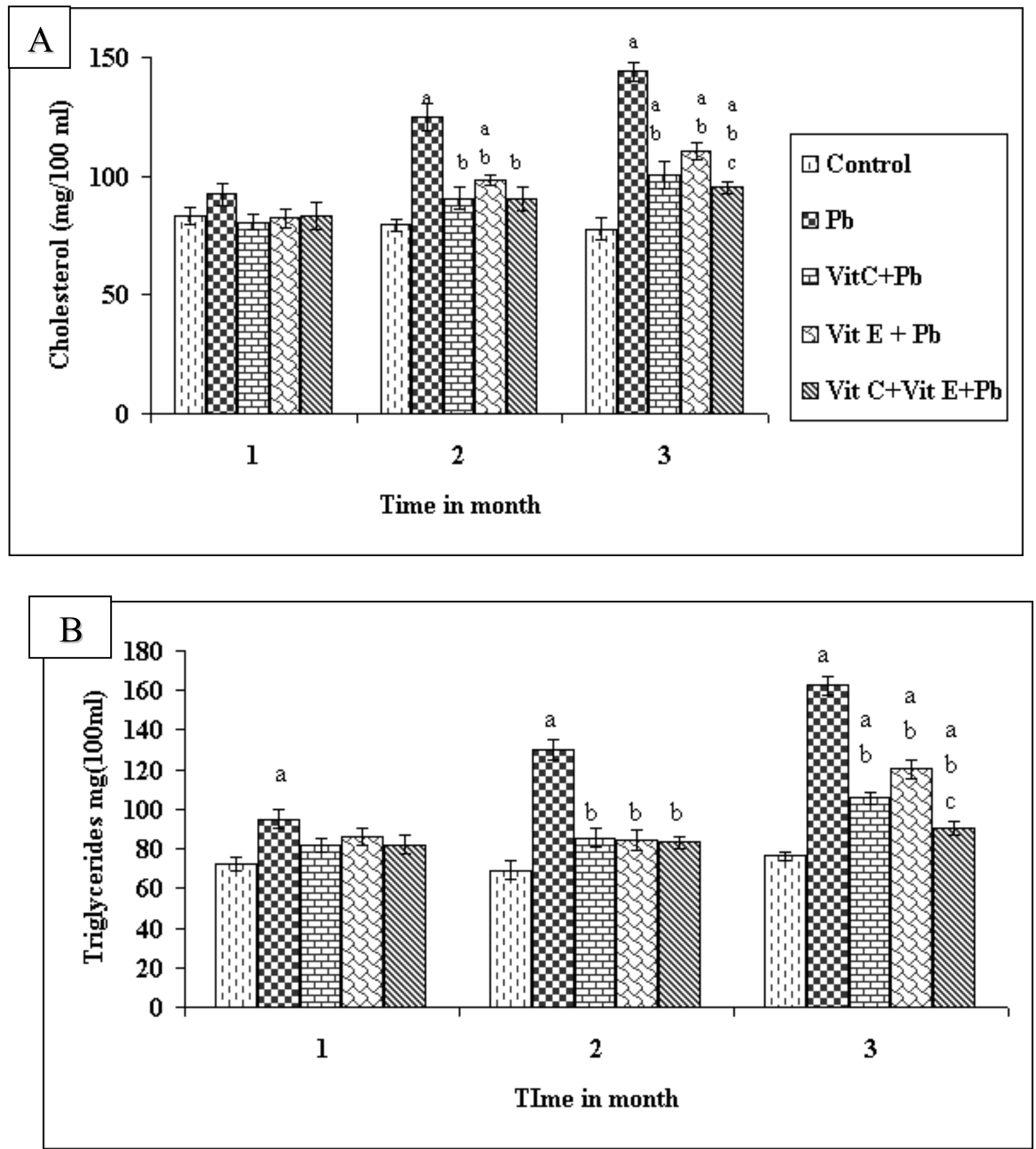

values are mean \pm S.E., $n=8$

a: Differ significantly compare to control, $\mathrm{P}<0.01$.

b: Differ significantly compare to $\mathrm{pb}, \mathrm{p}<0.01$.

C; Differe significantly compare to Vit C + pb or Vit E + pb 
Fig.(5): Effect of Vitamin C / Vitamin E either alone or in combination on plasma HDL and LDLlevels of lead treated rats
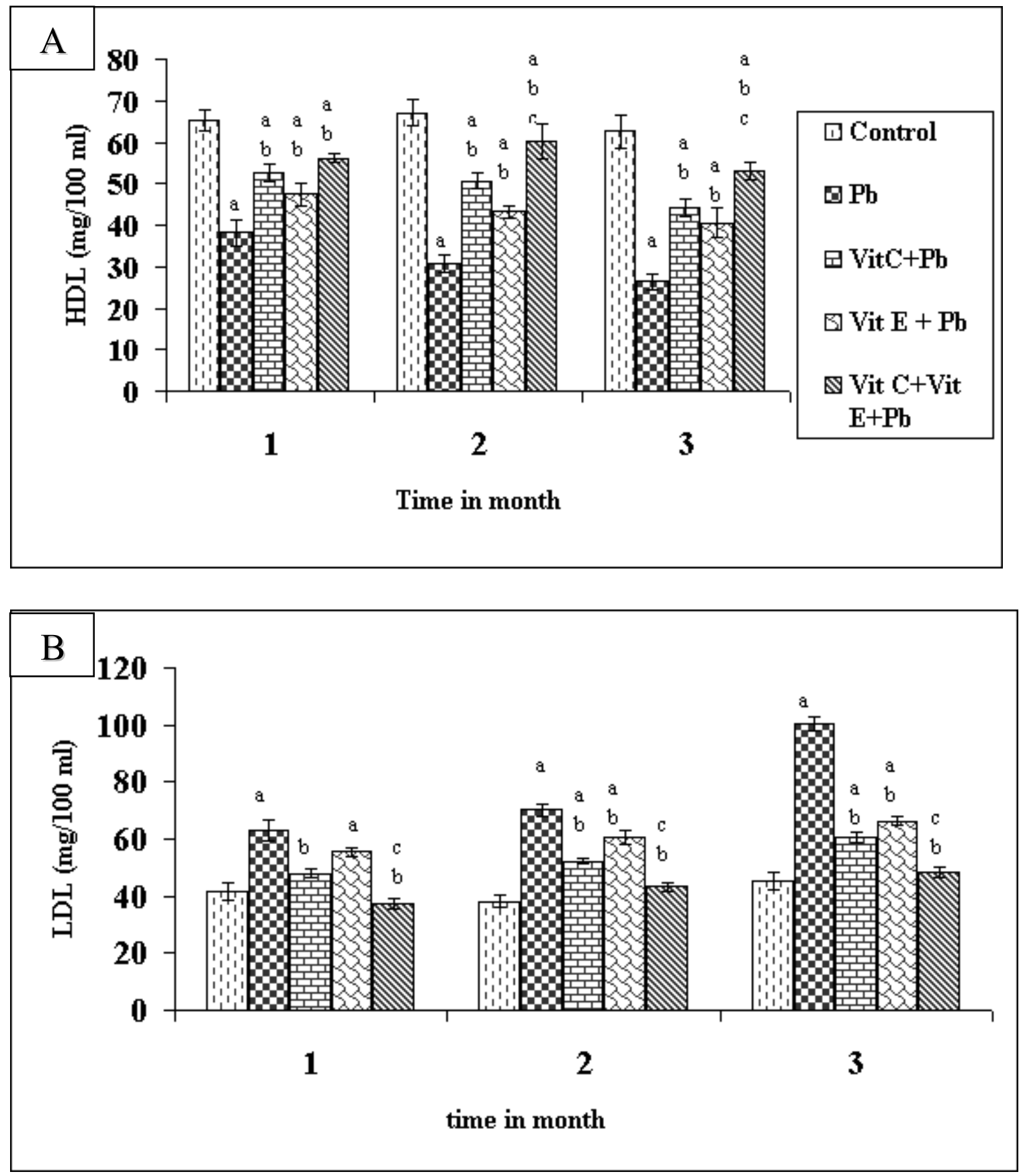

values are mean \pm S.E., $n=8$

a: Differ significantly compare to control, $\mathrm{P}<0.01$.

b: Differ significantly compare to $\mathrm{pb}, \mathrm{p}<0.01$.

C; Differe significantly compare to Vit C + pb or Vit E + pb 


\section{Discussion}

Lead is an environmental pollutant with no beneficial biological role. The higher concentration of lead in different tissues and RBCs following occupational or experimental exposure was associated with increased oxidative reaction, which might be responsible, at least in part, for leadinduced toxic effects (Gurer et al., 1998; Patra and Swarup, 2000). In the present study, subject of rats to lead caused elevation of blood lipid hydroperoxide level. A variety of analytical approaches are in use to measure the free radical mediated reactions and their metabolites to elucidate the occurrence of in vivo or in vitro lipid peroxidation. Among them measurement of lipid hydroperoxides (Wolff, 1994). One of the major concepts on the mechanism of heavy metal toxicity is attributed to its ability to generate reactive oxygen species which cause peroxidation of lipids. Lead is known to promote oxidative damage in liver by enhancing peroxidation of membrane lipids (Stohs and Bagchi, 1995), a deleterious process carried out by free radicals. Although the source of prooxidant during lead-induced oxidative stress is not known, it is suggested that autooxidation of accumulated amino levulinic acid due to inhibition of amino levulinic acid dehydratase, may result in the formation of superoxide and hydrogen peroxide (Monteiro et al., 1986), leading to production of more reactive hydroxyl radicals.

Free radicals overproduction following lead exposure intiates from mitochondria and spreads out quickly to all cellular and tissue components, causing dysfunction in cellular energy metabolism, membrane transportation and finally cell death. Another potent source of free radicals in the liver can be kupffer cells (Milosevic and Maier, 2000). In response, to oxidative stress induced by lead, endogenous antioxidants are consumed resulting in continuously decreasing tissue and cellular antioxidative capacity that leads to progressive oxidative injury (Patra et al., 2001). It was found a significant increase in lipid peroxidation and a decrease in the levels of endogenous antioxidants in the liver and kidney of lead exposed animals (Upasani and Balaraman, 2003). In another study of Flora et al. (2003), lead exposure produced significant depletion of hepatic GSH and catalase activity, while oxidized glutathione and lipid peroixdation levels increased significantly, pointing to hepatic oxidative stress.

In the current study the levels of blood GSH were decreased in lead treated rats. Lead stimulated lipid peroxidation in vivo resulted in the formation of aldehydic products which in turn caused a decrease in reduced glutathione content (Gurer et al., 1998). The depletion of glutathione and changes in the activities of various antioxidant enzymes indicative of lipid peroxidation have been implicated in lead induced oxidative damage (Donaldson and Knowles, 1993). GSH depletion enhances superoxide anion formation (Moriya et al., 2000). The observed increase in lipid hydroperoxide level of lead treated rats may result from decrease of GSH levels of the present study. Lead binds to sulfhydryl group of GSH, which could deplete the intracellular levels of GSH (Christie and Costa, 1984). It is concluded that the increase in the lipid peroxidation level lowered the GSH content in the tissues (Mezes et al., 1996).

Lead binds to plasmatic proteins and is conducted to liver, where it causes alterations in high number of enzymes. It can also perturb protein biosynthesis in hepatocytes, including the structural proteins (Goering, 1993). The observed decrease in protein content of plasma of rats treated with $\mathrm{Pb}$ may be due to decreased hepatic DNA (Shalan et al., 2005) and RNA contents (Stone and Fox, 1984). Protein and DNA decreases have been reported, since lead can interact with some amino acids of the enzymes (Needleman and Bellinger, 1991). It was reported that total protein and albumin were lowered in toads treated with lead (Chiesa et al., 2006). 
The toxic action produced by lead might be attributed to its ability to generate reactive oxygen species which induce oxidative damage in several tissues by enhancing lipid peroxidation that occurs readily in the tissues due to presence of membrane rich in polyunsaturated fatty acids (Cini et al., 1994). Traditionally evaluation of liver function is achieved by assessing the activities of hepatic enzymes in plasma such as ALT and AST. The change in enzyme activities in plasma is reflecting the amount of enzymes that leak out from the membrane of damaged hepatocytes, rather than the change in real liver function. The current study demonstrated a significant increase in ALT, AST and ALP in plasma of rats treated with lead. The increase in liver enzymes can be attributed to the increase in the level of lipid peroxidation.

It was noticed in the present investigation, a significant increase in plasma cholesterol, triglycerides and LDL-C and a significant decrease of HDL-C of the rats treated with lead. Knowles and Donaldson (1996) concluded that the increase in the levels of triglycerides in lead treated animals may indicate the breakdown of fatty acids. Plasma LDL can undergo reuptake in the liver via specific receptors and get cleared from circulation. This increased LDL concentration in plasma may be due to a defect in LDL receptor. HDL helps to scavenge cholesterol from extra hepatic tissues. Decreased HDL concentration can contribute to the increased cholesterol levels. There is evidence linking increased serum cholesterol and LDL levels to a higher risk for developing coronary heart diseases (Glueck et al., 1986).

The prevention of lipid peroxidation is essential for all aerobic organisms, and so the organism is well equipped with antioxidants that directly or indirectly protect cells against the adverse effects of xenobiotics, carcinogens and toxic radicals (Halliwell, 1995). Both vitamin $\mathrm{C}$ and vitamin $\mathrm{E}$ minimize adverse effects of lead on lipid hydroperoxide and GSH levels in the present investigation. It is, therefore, possible that restoration of altered biochemical parameters after concurrent Vit
$\mathrm{C}$ or Vit $\mathrm{E}$ administration must be responsible for the decreased oxidative stress and consequently an oxidation of GSH. Decreased level of lipid peroxidation after Vit $\mathrm{C}$ or Vit $\mathrm{E}$ treatment may save GSH from oxidation. Such a protective effect may be great importance so GSH may offer a first line of a defence against lead toxicity (Ishikawa and Sies, 1989). Vit $\mathrm{C}$ and Vit $\mathrm{E}$ are reported to act as an effective antioxidant for protection against diseases and degenerative process caused by oxidative stress (Chaudiere and Ferrari-Illiou, 1999). A potential role of vitamins $\mathrm{C}$ and $\mathrm{E}$ in modulating oxidative stress may determined their clinical usefulness as supplemental nutritional therapeutic agent in disorders affecting the free radical reactions. The treatment of rats prior of after stress with these vitamins resulted in an increase of antioxidant enzymes in the tissues as catalase and superoxide dismutase and GSH content with a decrease in lipid peroxidation (Kashif et al., 2004). Vit $\mathrm{C}$ and Vit $\mathrm{E}$ can ameliorate ROS in lead exposed animals (Hsu et al., 1998).

In the present study, Vit C and Vit E administration to rats treated with $\mathrm{Pb}$ reduced the alterations in protein, liver enzymes and lipid profile. It seems that the protective effect of vitamin $\mathrm{C}$ and $\mathrm{E}$ against lead poisoning refer to their antioxidant nature or their interference with intestinal absorption of lead (Pace and Iannucci, 1994). Vitamin $C$ as a chelating agent is reported in treatment of lead toxicity (Liobet et al., 1990). It reduces the possibility of lead interaction with critical biomolecules and factors inducing oxidative damage (Hsu and Gus, 2002). Vitamin C supplementation in lead exposed animals significantly reduced blood, liver and renal lead levels. Ascorbic acid might increase urinary elimination of lead (Dhawan et al., 1988). Vitamin $\mathrm{E}$ is an important antioxidant, residing mainly in cell membranes. It is thought to interrupt the chain reactions involved in lipid peroxidation and to scavenge ROS generated during oxidative stress (Palamanda and Kehrer, 1993).

In the current study, co-administration of both vitamin $\mathrm{C}$ and vitamin $\mathrm{E}$ to $\mathrm{Pb}$ - 
treated rats exhibited more protection than groups supplemented with either of the vitamins alone. Co-supplement of Vit $\mathrm{C}$ and Vit E, therefore could simultaneously improve the overall ability of scavenging free radicals from various tissues and cellular components, thus providing a synergistic effect to protect the liver from lead induced oxidative injury. The interaction among the two vitamins may maintain them in their reduced form to rebuild the endogenous antioxidant balances that could have been impaired by elevated oxidative stress following $\mathrm{Pb}$ administration. Oxidized Vit $\mathrm{E}$ is recycled to its reduced form by Vit $\mathrm{C}$, while oxidized Vit $\mathrm{C}$ is recycled to its reduced form by GSH (Fang and Yang, 2002). The synergistic action of both Vit C and Vit E against lead induced genotoxicity is reported (Mishra and Acharya, 2004). Moreover, Buettner (1993) found that vit C and Vit $\mathrm{E}$ jointly protected lipid structures against peroxidation. Also, the combination of vitamins $\mathrm{C}$ and $\mathrm{E}$ was found to partially improve disorders on pancreas and liver result from organsphophate insecticide, diazinon (Gokalp et al., 2004).

In conclusion, vitamin $\mathrm{C}$ or vitamin $\mathrm{E}$ may be useful as a prophylactic agent for lead poisoning. The combined supplementation with Vit $\mathrm{C}$ and Vit $\mathrm{E}$ highly protected rats from lead toxicity. It appears that vitamins $\mathrm{C}$ and $\mathrm{E}$ act synergistically in reducing lead toxicity.

\section{References}

1. Allain, C.C., Poon, L., Chan, C., Richmond, $W$ and Fu, P. (1974): Enzymatic determination of total cholesterol. Clin. Chem., 20: 470-475.

2. Beutler,E., Duron, D. and Kelly, B.M. (1963): Improved method for the determination of blood glutathione. J. Lab. Clin. Med., 61: 882-888.

3. Buettner, G.R. (1993): The packing order of free radicals and antioxidants: lipid peroxidation, $\alpha$-tocopherol and ascorbic acid. Arch. Biochem. Biophys., 300: 535-543.

4. Chaudiere, J. and Ferrari-Illiou, R. (1999): Intracellular antioxidant from chemical to biochemical mechanism. Food Chem Toxicol., 37: 949-962.
5. Chiesa, M.E., Rosenberg, C.E., Fink, N.E. and Salibian, A. (2006): Serum protein profile and blood cell counts in adult toads Bufo arenarum: effects of sublethal lead acetate Arch. Environ Contam. Toxicol., 50 (3): 384-391.

6. Christie, N.T. and Costa, M. (1984): In vitro assessment of the toxicity of metal compounds. IV. Disposition of metal in cells: Interaction with membranes, glutathione, metallothionein and DNA. Biol. Trace Elem. Res., 6: 139-158.

7. Cini, M., Fariello, R.Y.; Bianchettei, A. and Moretti, A. (1994): Studies on lipid peroxidation in the rat brain. Neurochem. Res., 19: 283-288.

8. Dhawan,M., Kachru, D.N. and Tandon, S.K. (1988): Influence of thiamine and ascorbic acid supplementation on the antidotal efficacy of thiol chelators in experimental lead intoxication. Arch. toxicol., 62: 301-304.

9. Donaldson, W.E. and Knowles, S.O. (1993): Is Lead toxicosis a reflection of altered fatty acid composition of membrane?. Comp. Biochem. Physiol. C, 104: 377-379.

10. El-Sokkary,G.H.,Abdel-Rahman, G.H. and Kamel, E.S. (2005): Melatonin protects against lead-induced hepatic and renal toxicity in male rats. Toxicology, 213: 25-33.

11. Ercal, N., Neal, R. Treeratphan, P., Lutz, P.M., Hammond, T.C., Dennery, P.A. and Spitz, D.R. (2000): A role of oxidative stress in suppressing serum immunoglobulin levels in lead exposed fisher 344 rats. Arch. Environ. Contam. Toxicol., 39 (2): 251-256.

12. Fang, Y.Z., Yang, S. And Wu, G. (2002): Free radicals, antioxidants and nutrition. Nutrition, 18 (10): 872-879.

13. Flora, S.J., pande, M. and Metha, A. (2003): Beneficial effect of combined administration of some naturally occuring antioxidants (vitamins) and thiol chelators in the treatment of chronic lead intoxication. Chem. Boil. Interact., 145: 267-280.

14. Fossati, P. and principe, L. (1982): Serum triglycerides determined colorimetrically with an enzyme that produces hydrogen peroxide. Clin. Chem., 28: 2077-2080.

15. Glueck,C.J.; Gordon, D.J. Nelson, J.J., Davis, C.E. and Tyroler, H.A. (1986): Dietary and other correlates of changes in total and low density lipoprotein cholesterol in hypercholesterolemic men: 
the lipid research clinics coronary primary prevention trail. Am. J. Clin. Nutr., 44: 489-500.

16. Goering, P.L. (1993): Lead-protein interactions as a basis for lead toxicity. Neurotoxicology, 14: 45-60.

17. Gokalp, D., Buyukvanli, B., Cicek, E., Ozer, M.K., Koyu, A., Altuntas, I. and Koylu,H. (2004): The effect of diazinon on pancreatic damage and ameliorating role of vitamin $\mathrm{E}$ and vitamin $\mathrm{C}$. pesticide Biochem. Physiol., 18: 584-594.

18. Gornall, A.C., Bardawill, C.J. and David, M.M. (1949): Determination of serum proteins by means of the Biuret reaction. J. Biol. Chem., 177: 751-766.

19. Grosicki, A. (2004): Influence of vitamin $\mathrm{C}$ on cadmium absorption and distribution in rats. J. Trace Elements in Med. Biol., 18 (2): 183-187.

20. Gurer, H., Ozgunes, H., Neal, R., Spitzand, D.R. and Ercal, N. (1998): Antioxidant effects of $\mathrm{N}$-acetyle cystein and succimer in red blood cells from lead exposed rats. Toxicology, 128: 181-189.

21. Halliwell,B.(1995): Antioxidant characterization, methodology and mechanism. Biochem. Pharmacol., 49: 1341-1384.

22. Hsu, P.C. Liu, M. Y., Hsu, C.C., Chen, L.Y. and Guo, Y.L.(1998): Effects of vitamin $\mathrm{E} /$ or $\mathrm{C}$ on reactive oxygen species related lead toxicity in the rat sperm. Toxicology, 128: 169-179.

23. Hsu, P.C. and Guo, Y.L. (2002): Antioxidant nutrients and lead toxicity. Toxicology, 180 (1): 33-44.

24. Ishikawa,T.,Sies, H. (1989): Glutathione as an antioxidant: toxicological aspects. In: Glutathione chemical, Biochemical and medical aspects, Dolphin, D., Poulson, R., Avramovic, O. Editors, Part B., Wiley, Interscience, New York, PP. 85-111.

25. Janisch K.M., Milde, J., Schempp, H. and Elstner, E.F. (2005): Vitamin C, vitamin $\mathrm{E}$ and flavonoids. Dev. Dphthalmol., 38: 59-69.

26. Jevtovic-Stoimenov, T., Kocic, G., Pavlovic, D. Stajanovic, I., Cvetkovic, T. and Sokolovic, D. (2003). Effects of captrol on membrance-associated enzymes in lead induced hepatotoxicity in rats. Acta Fac. Med. Naiss., 20 (3): 183-188.

27. Kannan, G.M. and Flora, S.J. (2004): Chronic arsenic poisoning in the rat: treatment with combined administration of succimers and an antioxidant. Ecotoxicol. Environ. Saf., 58 (1): 37-43.
28. Kashif, S.M., Zaidi, R. and Banu, N. (2004): Antioxidant potential of vitamins $\mathrm{A}, \mathrm{E}$ and $\mathrm{C}$ in modulating oxidative stress in rat brain. Clinica Chimica Acta, 340 (12): 229-233.

29. Kind, P.R.N. and King, E.G. (1954): Estimation of plasma phosphatase by determination of hydrolyzed phenol with amino antipyrine. J. Clin. Path., 7: 322-326.

30. Knowles, S.D. and Donaldson, W.E. (1996): Dietary lead alters fatty acid composition and membrane peroxidation in chick liver microsomes. Poutt. Sci., 75: 1498-1500.

31. Liobet, J.M., Dominco, J.L., Paternain, J.L. and Corbell, J. (1990): Treatment of acute intoxication. A quantitative comparison of a number of chelating agents. Arch environ contam. Toxicol 19: 185189.

32. Lopez-Virella, M.F., Stone, P., Ellis, S. A and collowell, J. (1977): Cholesterol determination in high-density lipoprotein by three different methods. Clin. Chem. 23 (5): 882-884.

33. Mezes, M. Virag, G., Barta, M. and Abouzeid, A.D. (1996): Effect of lipid peroxide loading on lipid peroxidation and on the glutathione and cytochrome systems in rabbits. Acta veter. Hungarica, 44 (4): 443-450.

34. Milosevic, N. and Maier, P. (2000): Lead stimulates intracellular signaling between hepatocytes and Kupffer cells. Europ J. Pharmacol., 401: 317-328.

35. Ming,Z.,Fan,Y.J., Yang, X.and Lautt, W.W (2006): Synergistic protection by Sadenosylmethionine with vitamins $\mathrm{C}$ and $\mathrm{E}$ on liver injury induced by thioacetamide in rats. Free Rad. Biol. Med., 40 (4): 617624.

36. Mishra, M. and Acharya, U.R. (2004): Protective action of vitamins on the spermatogenesis in lead treated swiss mice. J. Trace Elements Med. Biol., 18: 173-178.

37. Monteiro,H.P., Abdalla,D.S.P., Falijoni, A, A. and Bechera, E.H.J. (1986): Generation of active oxygen species during coupled autooxidation of oxyhemoglobin and amino levulinic acid. Biochem. Biophys. Acta., 881: 100-106.

38. Moriya, S., Yokoyama, H., Fukuda, M., Okamura, Y., Kamegaya, Y., Mizukami, T., Ohgo, H. and Tshii, H. (2000): Glutathione depletion enhances the formation of superoxide anion released 
into hepatic sinusoids after lipopolysaccharide challenge. Alcohol. Clin. Exp. Res., 24 (4): 59S-63S.

39. Needleman, H.L. and Bellinger, D. (1991): The health effects of low level exposure to lead. Annu. Rev. publ. Health, 12: 111-140.

40. Pace, V. and Iannucci, E. (1994): The importance of vitamins in relation to the presence of heavy metals in food. Panminerva Med., 36 (2): 80-82.

41. Palamanda, J.R. and Kehrer, J.P. (1993): Involvement of vitamin $E$ and protein thiols in the inhibition of microsomal lipid peroxidation by glutathione. Lipids, 28: 427-431.

42. Patra, R.C. and Swarup, D. (2000): Effect of lead on erythrocytic antioxidant defense, lipid peroxide level and thiol groups in calves. Res. Vet. Sci., 68: 71-74.

43. Patra, R.C., Swarup, D. and Dwivedi, S.K. (2001): Antioxidant effects of $\alpha$ tocopherol, ascorbic acid and Lmethionine on lead induced oxidative stress to the liver kidney and brain in rats. Toxicology, 162: 81-88.

44. Reitman, S. and Frankel, S. (1957): A colorimetric method for the determination of serum GOT and GPT. Am. J. Clin. Path., 28: 56-63.

45. Shalan, M.G., Mostafa, M.S., Hassouna, M.M., Hassab El-Nabi, S.E. and ElRefaie, A. (2005): Amelioration of lead toxicity on rat liver with vitamin $\mathrm{C}$ and silymarin supplements. Toxicology, 206 (1): 1-15.

46. Sukla, R., Dietrich, K.N., Bornchein, R.L. Berger, D. and Hammond, P.B. (1991): Lead exposure and growth in the early preschool child: a follow up report from the cinicnnati lead study. Pediatrics, 88: 886.

47. Sienra-Monge, J.J., Ramirez-Aguilar, M., Moreno-Macias, H., Reyes-Ruiz, N.I., Del Rio-Navarro, B.E. and RuizNavarro, M.X. (2004): Antioxidant supplementation and nasal inflammatory responses among young asthmatics exposed to high levels of ozone. Clin. Exp. Immunol., 138 (2): 317-322.

48. Sipos, P., Szentmihalyi, K., Feher, E., Abaza, M., Szilagyi M. and Blazovics, A. (2003): Some effects of lead contamination on liver and gallbladder bile. Acta Biol. Szeged., 47 (1-4): 139-142.

49. Sivaprasad, R. Nagaraj, M. and Varalakshmi, P. (2004): Combined efficacies of lipoic acid and 2,3-dimercaptosuccinc acid against lead induced lipid peroxidation in rat liver. J. Nutr. Biochem., 15 (1): 18-23.

50. Stohs, S.J. and Bagchi, D. (1995): Oxidative mechanisms in the toxicity of metal ions. Free Radical. Biol. Med., 18: 321-336.

51. Stone, C.L. and Fox, M.R. (1984): Effect of low levels of dietary lead and iron on hepatic RNA, protein and mineral in young Japanese quail. Environ. Res., 33 (2): 322-332.

52. Upsani, C.D. and Bataraman, R. (2003): Effect of vitamin $\mathrm{E}$, vitamin $\mathrm{C}$ and spirulina on the levels of membrane bound enzymes and lipids in some organs of rats exposed to lead. Indian J. pharmacol., 33: 185-191.

53. Vaziri, N.D., Liang, K. and Ding, $Y$. (1999): Increased nitric oxide inactivation by reactive oxygen species in lead induced hypertension. Kidney Int., 56 (4): 14921498.

54. Wan, X.S. Ware, J.H., Zhou, Z., Donahue, J.J., Guan, J. and Kennedy, A.R. (2006): Protection against radiation induced oxidative stress in cultured human epithelial cells by treatment with antioxidant agents. Int. J. Radiat Oncol. Biol. Phys., 64 (5): 1475-1481.

55. Winder, C. (1993): Lead, reproduction and development. Neurotoxicol., 14: 303318.

56. Wolff, S.P. (1994): Ferrous ion oxidation in presence of ferric ion indicator xygloenol range for measurement of hydroperoxide. Method Enzymol., 233: 182-189. 
تاثير فيتامين ج وفيتامين هـ على التقليل من الآثار السامة للرصاص على الكبل

\section{سمير عبد المنعم بثندي}

قسم علي الحيو ان، كلية العلوم ، جامعة الملك سعودـ المملكة العربية السعودية لمبية

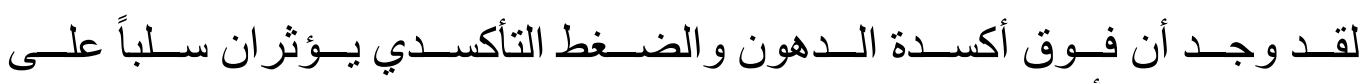

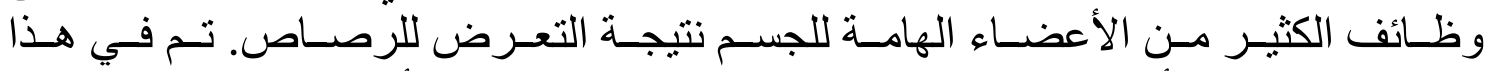

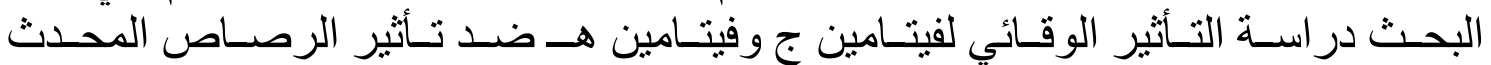

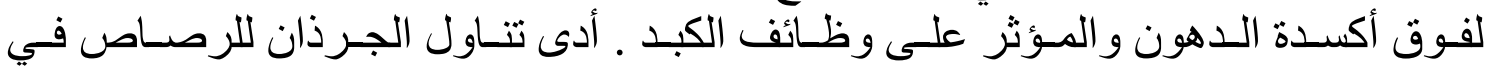

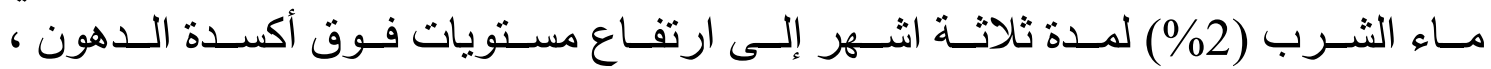

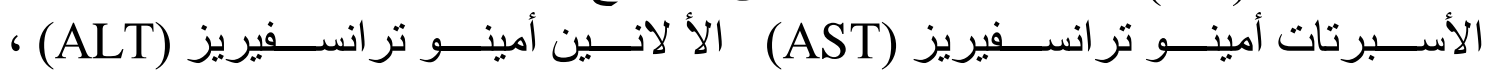

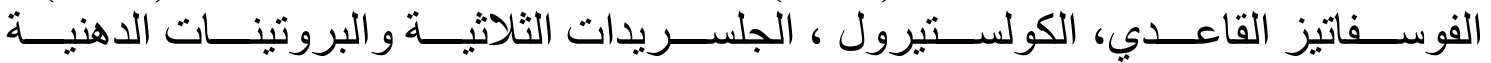

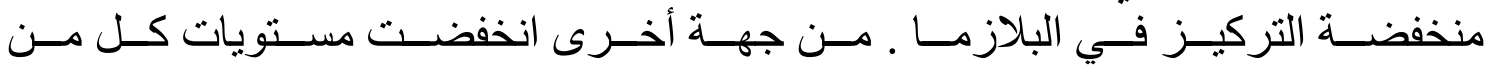

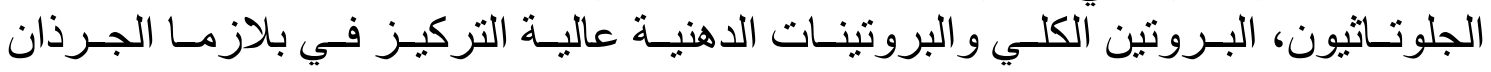

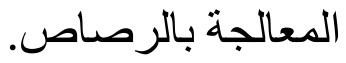

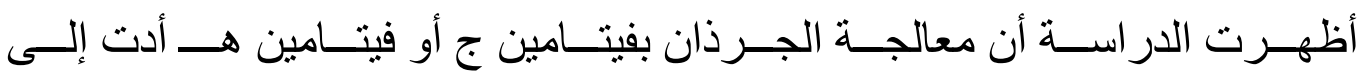

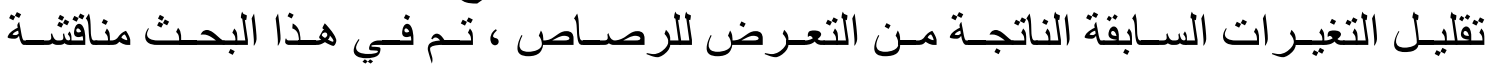

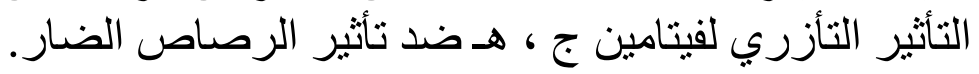

